\title{
Staelia culcita (Rubiaceae), a new species from Minas Gerais, Brazil
}

\author{
Roberto M. Salas* \& Elsa L. Cabral
}

Instituto de Botánica del Nordeste, Sargento Cabral 2131 c.c. 209 CP. 3400 and FACENA-UNNE. Corrientes, Argentina

*Author for correspondence: robertoymanuels@gmail.com

\begin{abstract}
Background - The genus Staelia (Rubiaceae) remains imperfectly known. As part of the revision of the genus by the first author, a new species is here described and illustrated.

Methods - Normal practices of herbarium taxonomy were used to study all the herbarium material available.

Key results - Staelia culcita R.M.Salas \& E.L.Cabral, a new species from Brazil, is described and illustrated. The new taxon is apparently endemic to the Espinhaço mountain range, Minas Gerais, in campos rupestres montane savannas. It resembles Staelia hatschbachii in its small habit but differs in the opposite and narrowly elliptic leaves with ciliate base (vs. whorled linear leaves with glabrous base), the corolla lobes that are distinctly shorter than the corolla tube (vs. corolla lobes equal or longer than corolla tube), the calyx lobes that are much shorter than the corolla tube (vs. calyx lobes longer than corolla tube) and the reticulo-papillate seed coat surface (vs. reticulo-foveate seed coat surface).

Conservation assessment - The species is only known from three localities, representing two locations. Based on the restricted area of occupancy and extent of occurrence and based on the continuing decline in area, extent and quality of habitat, the species should be considered as Endangered: EN B1a,b(iii) + B2a,b(iii).
\end{abstract}

Key words - Cadeia do Espinhaço, campos rupestres, endangered species, IUCN, Spermacoceae, Staelia.

\section{INTRODUCTION}

Staelia Cham. \& Schltdl. belongs to the Spermacoceae tribe (Robbrecht \& Manen 2006, Kårehed et al. 2008, Groeninckx et al. 2009). The genus comprises 17 species and is endemic to South America (Salas \& Cabral 2010a). It was first described by Chamisso \& Schlechtendal (1828) based on Staelia thymoides Cham. \& Schltdl. Schumann (1888) proposed an infrageneric classification of Staelia and grouped the then known species into three sections. Staelia sect. Staelia K.Schum. comprised seven species of which two were new to science and two were new combinations. Staelia sect. Tessiera (DC.) K.Schum. was based on the genus Tessiera described by de Candolle (1830) including Tessiera lanigera DC. from Brazil and Tessiera lithospermoides DC. from Mexico. Schumann added a third species to this section, i.e. Staelia capitata K.Schum. Staelia sect. Anthospermopsis K.Schum. was a monospecific section which contained Staelia catechosperma K.Schum. This last section was elevated to the generic rank (Anthospermopsis (K.Schum.) J.H.Kirkbr.) by Kirkbride (1997), based on the peculiar dehiscence type of the fruit.

Based on morphological studies of taxa historically and morphologically related to Staelia, we have recently proposed the three following amendments to this classification
(Salas \& Cabral 2010b, 2010c). (1) The two Brazilian species of sect. Tessiera (Staelia capitata and S. lanigera) were segregated into a new genus called Planaltina R.M.Salas \& E.L.Cabral. (2) The genus Tessiera, included in Staelia by Schumann, was reinstated to the generic status and lectotypified based on the Mexican species Tessiera lithospermoides. (3) All species with the fruit dehiscence similar to that of the type species were kept within Staelia s. str. In these species the capsule is separated into three parts: two apical caducous pieces and one basal piece that persists on the pedicel. The dehiscence begins longitudinally from the apex to the middle of the capsule along the carpels (septifragal), subsequently the line of dehiscence leaves the septum and goes all the way across the fruit wall of each valve from one side of the septum to the other. The persistent portion is formed by the intercarpelar septum, the base of the fruit and the pedicel. A profile view shows a notorious oblique cut. In addition, the genus can also be characterized as herbs or subshrubs, with mostly pseudoverticillate (leafy brachyblasts in the axil of each leaf), rarely verticillate leaves, with glomerules, 2-lobed calyces, 4-lobed corollas and 7-10-zonocolporate pollen grains of small or medium size.

The genus Staelia is currently under revision by the first author and several new species have been described (Salas \& 


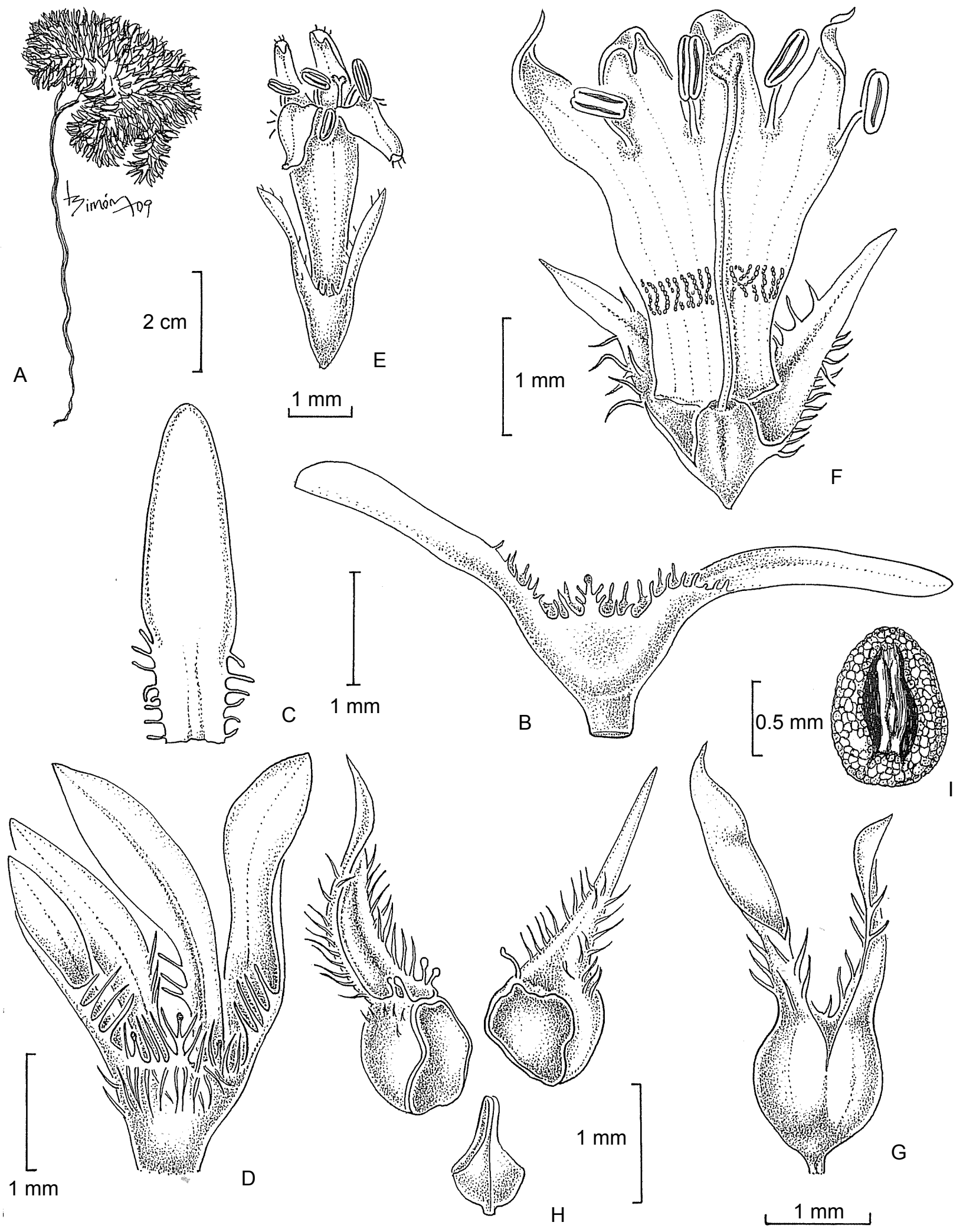

Figure 1 - Staelia culcita: A, habit; B, foliar nude showing the opposite leaves without brachyblast; C, leaf with ciliate base; D, foliar node with brachyblast and stipule with colleters; E, flower; F, calyx and corolla open; G, subspherical immature fruit; H, dehiscent fruit; I, seed. From Hatschbach \& Silva 64169 (CTES). Drawn by Laura Simón. 
Cabral 2006a, 2006b, 2010a). The aim of this work is to describe a new species found in the montane savannas of Brazil.

Normal practices of herbarium taxonomy were used to study all the herbarium material available. For SEM studies, seeds were directly mounted on stubs and covered with goldpalladium. Photographs were taken with a Jeol 5800 LV SEM (from SGCYT-UNNE).

\section{RESULTS AND DISCUSSION}

\section{Staelia culcita R.M.Salas \& E.L.Cabral sp. nov.}

Staelia hatschbachii similis, sed foliis oppositis, ellipticis vel anguste ellipticis, cum venis pubescentibus et margine ciliato (nec foliis verticillatis linearibus, glabris), laciniis stipularibus ciliatis (nec pubescentibus) atque seminibus cum testa reticulo-papillata et pariete digitata (nec testa reticulo-areolata vel reticulo-foveata et pariete laevigata) differt. - Type: Brazil: Minas Gerais, Rio Vermelho, Estrada Diamantina- São

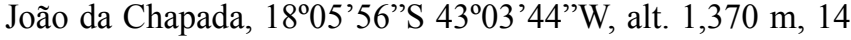
Jan. 1998, J.R. Pirani et al. 3881 (holo-: SPF; iso-: HUEFS).

$\underline{\text { Subshrub}}$, erect, much branched, $2-5 \mathrm{~cm}$ tall. Stems cylindrical to quadrangular, pubescent. Leaves sessile; leaf blades $1.2-3.5 \times 0.2-1.2(-1.5) \mathrm{mm}$, elliptic or narrowly elliptic, adaxial glabrous, abaxial pubescent at the veins, slightly succulent; base slightly attenuated, ciliolate; apex truncate; primary veins visible only on adaxial face, secondary veins obscure. Stipules $0.6-0.8 \mathrm{~mm}$ long, interpetiolar, forming a sheath, glabrous; edge with 3-5 bristles, $0.2-0.4 \mathrm{~mm}$ long, the central colleter-tipped. Inflorescences 1-3-flowered, subtended by 2 bracts. Flowers 4-merous; calyx 2-lobate, triangular, 1.5-2.4 mm long, margin ciliolate at the base, shorter than the corolla tube; corolla light purple, 3-3.5 mm long, corolla tube 2 times longer than the corolla lobes, with a ring of moniliform hairs at the middle inside. Stamens shorter than the corolla lobes; anthers $0.4-0.5 \mathrm{~mm}$ long. Hypanthium $0.8-$ $1 \mathrm{~mm}$ long, glabrous; style 3-3.5 mm long; stigma bifid, stigmatic branches $0.1-0.2 \mathrm{~mm}$ long; nectary disc entire. Fruits dry, dehiscent, $1.2-1.3 \times 1.25-1.3 \mathrm{~mm}$, subspherical, glabrous. Seeds obovoid, 0.9-1 mm long; ventral surface with narrowly longitudinal furrow, covered by hyaline strophiole; testa reticulo-papillate, cells irregularly tetragonal on dorsal face and digitate around the ventral groove, periclinal walls raised, anticlinal walls straight or sinuous. Figs $1 \& 2$.

Distribution - Brazil, endemic to Minas Gerais, apparently restricted to the Espinhaço mountain range.

Phenology - All the material observed has flowers and fruits in January.

Habitat - It grows in Campos Rupestres (rocky fields) montane savannas, at an altitude ranging between 1,100 and 1,400 $\mathrm{m}$. This area is located within the Espinhaço mountain range. It harbors numerous endemic species and several new species are described each year (Roque 2001, Rapini et al. 2002, Konno et al. 2006, Louzada \& Versieux 2010).

Conservation assessment - The species is only known from three localities, representing two locations, all outside pro-
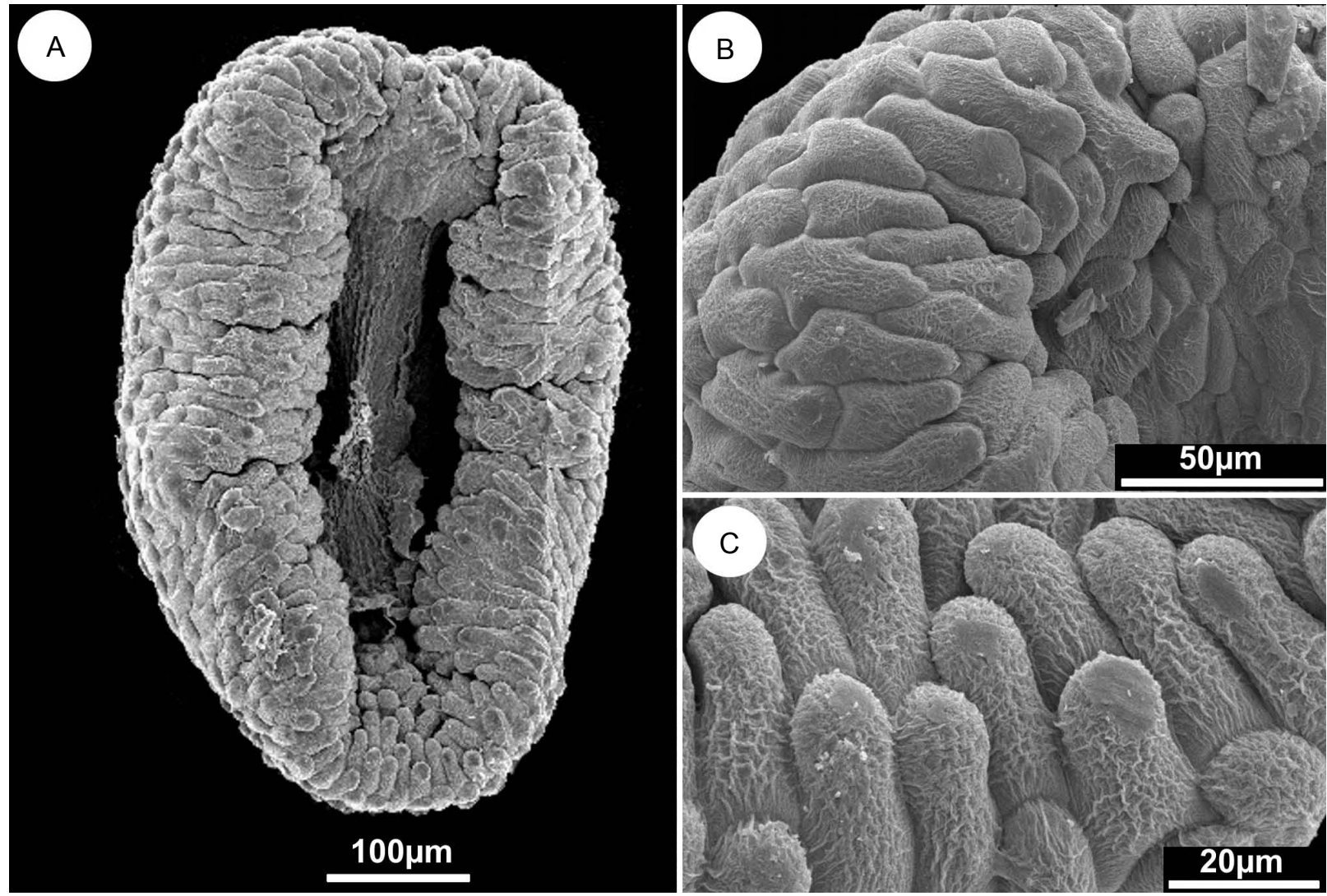

Figure 2 - Staelia culcita, seed: A, ventral view of seed; B, ventral apex of seed; C, papilla of the ventral base of seed. SEM micrographs from Pirani 3881 (HUEFS). 
tected areas. The extent of occurrence was calculated to be $268.47 \mathrm{~km}^{2}$. The area of occupancy is estimated at $29.96 \mathrm{~km}^{2}$ (cell size 3.16). There is a continuing decline in area, extent and quality of habitat. Therefore, following the IUCN criteria (IUCN 2001), the species should be considered as Endangered: EN B1a,b(iii) + B2a,b(iii).

Paratypes - Brazil: Minas Gerais Brazil: Minas Gerais, Francisco Dumont, Serra do Cabral, Estrada Várzea da Palma, pelo alto da Serra, Fazenda Serra do Cabral Agro-Industria S.A., 17²41'56.3”S 44¹7'31.7'W, alt. 1,100 m, 11 Jan. 1998, J.R. Pirani et al. 3980 (SPF); Várzea de Palma, Agropecuária Serra do Cabral, G. Hatschbach \& J.M. Silva 64169 (CTES, MBM).
Etymology - The specific epithet 'culcita' (= small cushion) refers to the compact and much-branched habit of the plant. In their natural habitat this small plant is partially covered by white sand and only the apical branches and its few flowers are visible.

Notes - Staelia culcita is related to S. hatschbachii, which is endemic to the Grão Mogol region, also in the Espinhaço mountain range. The two species are easily confused morphologically, especially in herbarium material. The differential characters of both species are summarized in the following key:

\section{Key to Staelia culcita and Staelia hatschbachii}

1. Leaves elliptic or narrowly elliptic, opposite, adaxial glabrous, abaxial pubescent at the veins, slightly succulent; base ciliate; apex truncate or blunt. Stipules glabrous or with long hairs at the apex, with 5 bristles, the central ciliate and glandular. Calyx lobes shorter than the corolla tube, glabrescent, with ciliate margin. Corolla lobes 1-2 times shorter than the tube. Stigma bifid; stigmatic branches $0.1-0.2 \mathrm{~mm}$ long. Capsules subspherical. Seed coat surface reticulopapillate, with digitate cells around the ventral groove.............................Staelia culcita

1'. Leaves linear, whorled, glabrous, slightly leathery; base glabrous; apex acute. Stipules glabrescent or pubescent, with 3 pubescent bristles. Calyx lobes longer than the corolla tube, glabrous. Corolla lobes equal or longer than the tube. Stigma notoriously bifid; stigmatic branches $0.9-1.1 \mathrm{~mm}$ long. Capsules obovoid. Seed coat surface entirely reticulo-foveate..................................Staelia hatschbachii

\section{ACKNOWLEDGMENTS}

We thank Laura Simon for preparing the illustration and to the curators of HUEFS and SPF herbaria, Luciano P. Queiroz and Renato Mello-Silva respectively. Financial support was provided by IBONE-CONICET and the Myndel Botanical Foundation.

\section{REFERENCES}

Chamisso L.A, Schlechtendal D.F.L. (1828) De plantis in expeditione speculatoria Romanzoffiana observatis. Linnaea 3: 338366. [Biodiversity Heritage Library: http://www.biodiversitylibrary.org/item/10847\#page/510/mode/1up]

de Candolle A.P. (1830) Rubiaceae, Spermacoceae. Prodromus systematis naturalis regni vegetabilis 4: 538-578. Strasbourg, Treuttel \& Würtz.

Groeninckx I., Dessein S., Ochoterena H., Persson C., Motley T.J., Kårehed J., Bremer B., Huysmans S., Smets E. (2009) Phylogeny of the herbaceous tribe Spermacoceae (Rubiaceae) based on plastid DNA data. Annals of the Missouri Botanical Garden 96: 109-132.

IUCN (2001) IUCN Red List Categories and Criteria, Version 3.1. Gland, Switzerland and Cambridge, United Kingdom, IUCN Species Survival Commission.

Kårehed J., Groeninckx I., Dessein S., Motley T.J., Bremer B. (2008) The phylogenetic utility of chloroplast and nuclear DNA markers and the phylogeny of the Rubiaceae tribe Spermacoceae. Molecular Phylogenetics and Evolution 49: 843-866. doi:10.1016/j.ympev.2008.09.025

Kirkbride J.H. (1997) Manipulus rubiacearum VI. Brittonia 49: 376-378. doi:10.2307/2807836
Konno T.U.P., Rapini A., Goyder D.J., Chase M.W. (2006) The new genus Minaria (Asclepiadoideae, Apocynaceae). Taxon 55: 421-430. doi: $10.2307 / 25065588$

Louzada R.B., Versieux L.M. (2010) Lapanthus (Bromeliaceae, Bromelioideae): a new genus from the Southern Espinhaço Range, Brazil. Systematic Botany 35: 497-503. doi:10.1600/036364410792495908

Rapini A., Mello-Silva R., Kawasaki K.L. (2002) Richness and endemism in Asclepiadoideae (Apocynaceae) from the Espinhaço Range of Minas Gerais, Brazil - a conservationist view. Biodiversity and Conservation 11: 1733-1746. doi:10.1023/A:1020346616185

Robbrecht E., Manen J.F. (2006) The major evolutionary lineages of the coffee family (Rubiaceae, angiosperms). Combined analysis (nDNA and cpDNA) to infer the position of Coptosapelta and Luculia, and supertree construction based on rbcL, rps16, trnL-trnF and atpB-rbcL data. A new classification in two subfamilies, Cinchonoideae and Rubioideae. Systematics and Geography of Plants 76: 85-146. [available at http://www.ingentaconnect.com/content/nbgb/sgp/2006/00000076/00000001/ art00002]

Roque N. (2001) Five new species of the genus Richterago Kuntze (Compositae, Mutisieae): an endemic genus from Brazil. Novon 11: 341-349. [JSTOR: http://www.jstor.org/pss/3393043]

Salas R.M, Cabral E.L. (2006a) Una nueva especie y una nueva combinación en el género Staelia (Rubiaceae-Spermacoceae) de Bolivia. Darwiniana 44: 500-503.

Salas R.M., Cabral E.L. (2006b) Una especie nueva del género Staelia (Spermacoceae-Rubiaceae) para la flora de Brasil. Revista de Biologia Neotropical 3: 1-3.

Salas R.M., Cabral E.L. (2010a) The species of the genus Staelia (Rubiaceae) from Paraguay, a new species and new synonym. Blumea 55: 125-128. [available at http://www.ingentaconnect. com/content/nhn/blumea/2010/00000055/00000002/art00006] 
Salas R.M., Cabral E.L. (2010b) Planaltina, nuevo género de la tribu Spermacoceae (Rubiaceae), endémico del Planalto Central de Brasil y una nueva especie del estado de Goiás, Brasil. Journal of the Botanical Research Institute of Texas 4: 193-206.

Salas R.M., Cabral E.L. (2010c) Rehabilitación y lectotipificación del género Tessiera, su relación con Diphragmus y Staelia (Spermacoceae-Rubiaceae): una nueva combinación y un nuevo sinónimo. Journal of the Botanical Research Institute of Texas 4: 183-194.
Schumann K. (1888) Rubiaceae. In: Martius C.P.F. (ed.) Flora Brasiliensis 6(6): 71-76. Fleischer, Leipzig. [BHL: http://www.biodiversitylibrary.org/item/9667\#page/43/mode/1up]

Manuscript received 15 Dec. 2010; accepted in revised version 22 Aug. 2011.

Communicating Editor: Steven Dessein. 